\title{
Die wysgerige agtergrond van die Hervormde teologiese opleiding aan die Universiteit van Pretoria
}

\author{
PS Dreyer \\ Emeritus professor, Universiteit van Pretoria
}

\begin{abstract}
The philosophical background of the theological training of the Nederduitsch Hervormde Church of Afrika at the University of Pretoria

Since the inception of the theological training of the Nederduitsch Hervormde Church of Africa at the University of Pretoria in 1917 philosophy has been a mandatory subject for all propaedeutic theological students. The history of the Department of Philosophy is traced to show the prevalent types of philosophy taught in the Department, because the philosophical training is considered important as preparation for theological training.
\end{abstract}

Wysbegeerte aan die Universiteit van Pretoria was van die begin af 'n verpligte vereiste waaraan 'n student moes voldoen voordat hy tot die teologiese studie toegelaat is.

Die tese waarvandaan hierdie artikel uitgaan, is dat die wysgerige studie nie net 'n teologiese student van die nodige kennis voorsien nie, maar die student ook vorm. Die belangrikste is dat dit hom bepaalde denkmetodes leer en hom in sy denke dissiplineer. Verder is dit belangrik dat die student hierdie vorming kry voordat hy met die teologiese opleiding begin.

As ons hierdie tese aanvaar, spreek dit vanself dat die aard en rigting van die wysgerige studie vir die teologie belangrik is. Omdat die teologie wat doseer word, ' $n$ bepaalde stempel dra, spreek dit ook vanself dat die soort wysbegeerte wat die student ontvang, vir die teologie belangrik is, omdat die wysgerige skoling by die teologiese skoling kan aansluit of vreemd daarteenoor kan staan, die teologiese skoling kan steun of dit kan belemmer. 
Die doel van hierdie artikel is om 'n skets van die geskiedenis van die vak Wysbegeerte aan die Universiteit van Pretoria te gee, egter nie as 'n doel in sigself nie, maar as deel van die agtergrond van die teologiese opleiding. Aan die Universiteit van Pretoria is daar net een Departement Wysbegeerte en al die studente van die Nederduitsch Hervormde Kerk en sommige studente van die Nederduitse Gereformeerde Kerk neem dieselfde kursusse in Wysbegeerte. Hierdie artikel het die teologiese opleiding van die Nederduitsch Hervormde Kerk in gedagte, hoewel wat hier gesê word, ewe goed ook vir die teologiese opleiding van die Nederduitse Gereformeerde Kerk geldig is.

Die verversingspos aan die Kaap is in 1652 gestig. In daardie tyd was die Kaap s6 anders as Europa dat die stigting net so goed op ' $n$ ander planeet kon gewees het. Die ekonomiese, politieke, sosiale en kerklike omstandighede in Europa het saamgewerk om op die stigting van die verversingspos uit te loop. Die mense wat hulle aan die Kaap gevestig het, was Europeane, mense met 'n baie lang geskiedenis en tweeduisend jaar van hoë beskawing. Dit het alles 'n bepaalde stempel aan die Kaapse nedersetters gegee - die feit dat hulle Westerlinge was, Hollands gepraat het, 'n bepaalde godsdiens en besondere godsdienstige oortuigings gehad het en so meer. Dit was die begin van 'n Westerse volk in Suid-Afrika, wat sy besondere aard in 'n groot mate dank aan die besondere aard van die mense wat hulle aan die Kaap kom vestig het. Na 1652 was die Kaap gedurig in die skaduwee van Europa en het die geskiedenis van Europa in 'n baie groot mate die geskiedenis van Suid-Afrika bepaal, selfs in so ' $n$ mate dat die Hollandse bewind deur 'n Engelse bewind vervang is, met al die gevolge wat dit gehad het.

Desondanks is die geskiedenis van die mense in Suid-Afrika iets totaal anders as die geskiedenis van die mense in Europa. As 'n mens jou met Europa besig hou, het jy met geweldige dinge te make - die Griekse en Romeinse beskawings, die begin van die Christendom, die Middeleeue, die Renaissance en die begin van die Moderne Tyd met die opbloei van die natuurwetenskap en tegniek, die Kerkhervorming, die kom en gaan van manne wat die lewe van die hele wêreld verander het. Dit is grootse, opwindende gebeurtenisse en mense wat jou byna uitasem laat staan. As jy na die Kaap kyk, sien jy sekere gevolge van wat in Europa gebeur het, soos die pogings van die Britse bewind om die Kaap te verengels, maar van die geestesstrominge van Europa sien jy merkwaardig min. John Locke se filosofie wat 'n geweldige invloed op die Amerikaanse onafhanklikheidstryd en die Franse Rewolusie gehad het, gaan by die gewone mense van die Kaap ongemerk verby; ook die Kommunistiese Manifes van Karl Marx, wat gepubliseer is vyf jaar voor ds Dirk van der Hoff in Potchefstroom aangekom het, het Europa laat kook, maar geen rimpeling in Suid-Afrika gemaak nie. 
Die redes daarvoor is talryk, maar moet hoofsaaklik in die omstandighede van die Blankes in Suid-Afrika gesoek word. Hulle was pioniers, besig om ' $n$ land mak te maak. Hulle was boere in 'n land sonder industrieë. Hulle het weinig onderrig gehad in 'n land waar geen universiteite en net elementêre skoolonderwys bestaan het. Hulle primêre probleem was om aan die lewe te bly en hulleself as blanke, Christelike Westerlinge te handhaaf. Daarvoor was hulle tradisies baie belangrik, maar die allerbelangrikste was hulle godsdiens. In hierdie godsdiens was hulle op hulle besondere manier baie sterk behoudend. As gevolg van al hierdie faktore het die wysgerige en teologiese strominge wat in Europa op baie terreine soveel stryd en beroering veroorsaak het, hulle feitlik nie aangeraak nie.

Die Kaap het onder die Vereenigde Oost-Indische Compagnie gestaan wat ook vir die kerklike versorging, insluitende die voorsiening van predikante, verantwoordelik was. Beide die Vereenigde Oost-Indische Compagnie en die StatenGeneraal het as streng beleid die Calvinisties-Hervormde godsdiens gehandhaaf. Dit is begrypbaar, omdat die Nederlandse Hervormde Kerk die staatskerk in Nederland was, en beide die Vereenigde Oost-Indische Compagnie as handelsonderneming en die regering nie in godsdienstige en kerklike struwelinge in die kolonies betrokke wou raak nie, nie net om gadsdienstige redes nie, maar ook (en miskien veral) omdat dit bestuursprobleme kon oplewer.

Die mate waarin Europese geestesstrominge tot Suid-Afrika deurgedring het, was feitlik geheel en al tot die gesofistikeerde samelewing van Kaapstad en in 'n baie mindere mate die dorpe beperk. Die nedersetters was oor die algemeen baie eenvoudige mense, nog meer so die veeboere op die oos- en noordoosgrens. Hierdie mense was gelowige Calviniste, met 'n baie letterlike interpretasie van die Bybel. Die rasionalistiese wending wat die Calvinisme in Nederland geneem het, het eers laat in die negentiende eeu 'n mate van invloed onder hulle gekry. Die Engelse godsdienstige strominge, met name die Metodisme met sy oordrewe emosionaliteit, het na 1812 saam met die Skotse predikante groot invloed in die Kaapkolonie en na 1848 in ' $n$ baie mindere mate in die Vrystaat uitgeoefen. Hierdie invloed was byna net beperk tot die meer gesofistikeerde en ontwikkelde dorpenaars van die Weskaap, waar daar Skotse predikante was, en verder tot die agternatrekkers wat uit hierdie kringe na die anneksasie van die Vrystaat daarheen getrek het. Die binnelandse veeboere se kerklike verbinding met Nederland is in 1806 verbreek, maar toe hulle rondom 1836 na die noorde trek, was dit nog die gees van die Hollandse tydperk wat hulle besiel het. Hulle het Calviniste gebly, maar nooit in 'n dooie rasionalisme en wettisisme verval nie. Daar was by hulle 'n innigheid, die warm vroomheid en 'n persoonlike verhouding met God, wat egter nie die gevolg van die Metodisme nie, maar van die enkele skrywers wat naas die Bybel hulle leesstof 


\section{Wysperige agtergrond}

uitgemaak het, skrywers soos á Brakel en andere (vgl Gedenkalbum 1986: 12vv).

Toe die Trekkers in die binneland kerklik 'n selfstandige weg volg, soek hulle aansluiting by die Kerk wat hulle nog onthou het en wat hulle as hulle soort kerk beskou het, naamlik die Nederlandse Hervormde Kerk. Uit hierdie moederkerk het die Nederduitsch Hervormde Kerk van Afrika aanvanklik al sy predikante gekry, en ons eie seuns wat as predikante opgelei is, is aan die teologiese fakulteite opgelei wat deur die Nederlandse Hervormde Kerk beman is. Tussen hierdie predikante was daar 'n avis rara of twee, maar as 'n mens aan die wysgerige en teologiese geskiedenis van Europa, in besonder Nederland, dink, is dit merkwaardig hoe weinig van hierdie geskiedenis se produkte by ons tereg gekom het, en ewe merkwaardig hoe min invloed daardie enkeles kon uitoefen. Dit moet aan die uitsoek van die predikante gedank word, maar veral aan die gees en oortuigings van die kerklike publiek, waarmee die gees en oortuigings van die landsowerheid saamhang. 'n Predikant kan met afwykende idees en aktiwiteite ook maar net so ver kom as wat sy gemeente hom toelaat.

Die Nederduitsch Hervormde Kerk van Afrika kry die geleentheid tot teologiese selfstandigheid toe die Kerk in 1917 met sy eie teologiese opleiding aan die Universiteit van Pretoria begin het. Van die teologiese selfstandigheid kom daar aanvanklik egter weinig tereg. Ook die teologie van hierdie opleiding bly dubbeld verbind: Aan die een kant is die Nederduitsch Hervormde teologie aan die teologie van Nederland verbind. Tot die Tweede Wêreldoorlog toe het alle Hervormde predikante wat gepromoveer het, aan Nederlandse universiteite gepromoveer, en alle professore wat deur die Kerk aangewys is, was of Nederlanders of Afrikaners wat in Nederland gepromoveer het. Die teologie van die Fakulteit in Pretoria was die teologie wat die professore in Nederland leer ken het, en die Nederlandse teologie was deel van die breër verband van die Duitse teologie. (Onder 'Duits' moet die hele Duitstalige gebied verstaan word en sluit ook Switserland, Oostenryk en so meer in.) Teologiese strominge wat nie primêr Nederlands of Duits was nie, is deur die Nederlands-Duitse bril gesien. 'n Mooi voorbeeld hiervan is die teologie van Calvyn. Hierdie teologie het in verskillende lande groot aanhang gekry. In Frankryk is Calvyn se teologie hoofsaaklik deur die godsdiensoorloë byna uitgewis, maar het in Skotland floreer, terwyl daar in die eerste deel van die negentiende eeu sterk Skotse invloed in die Kaapse kerk was. Ons Hervormde Calvinisme dra egter geen Franse of Skotse stempel nie, maar 'n Nederlands-Duitse. Ons het ons Calvinisme via die Nederlanders gekry.

Eers die Tweede Wêreldoorlog bring dit mee dat Hervormde predikante aan die Pretoriase Fakulteit verder studeer en die eerste een promoveer 'n ruk na die oorlog beëindig is. Na mate die verhouding tussen Nederland en Suid-Afrika na 
die oorlog versleg het, het die verhouding tussen die Nederlandse en die Nederduitsch Hervormde Kerk ook agteruitgegaan. Dit het by die Nederduitsch Hervormde Kerk 'n selfstandigheid teenoor die Nederlandse Kerk meegebring, wat gemaak het dat die Nederduitsch Hervormde teoloë wyer as Nederland begin kyk het. Weens die onvriendelike houding van sommige Nederlandse teoloë, maar veral van die Nederlandse studente, het ons studente al meer na ander lande toe begin gaan en enkeles het reeds buite Nederland gepromoveer. Die teologiese rigting van die Nederduitsch Hervormde Kerk het egter daarmee nie noemenswaardig verander nie, en die oorgrote aantal studente gaan nou na Duitstalige universiteite.

Waar ons teologie aan die een kant nog steeds aan die Nederlands-Duitse teologie gebind is, is dit aan die ander kant net soos vroeër aan die aard en gees van die Hervormde kerkvolk gebind. Ons kerkvolk word deur sy eie soort konserwatisme gekenmerk. Op welke weë die teoloog hom ook al mag begewe, as hy hierdie tweede binding vergeet, is sy toekoms nie baie rooskleurig nie. Dit het gemaak dat baie teologiese strominge by die Hervormde Kerk verbyvloei as dinge waaraan 'n mens akademies aandag gee, maar sonder dat dit die Kerk ooit werklik aangeraak het.

Die Hervormde teologiese opleiding begin dan in 1917 aan die destydse Transvaalse Universiteitskollege met dr JHJA Greyvenstein as professor. Dr E MacMillan (Presbiteriaan) het ook teologie doseer, terwyl prof AC Patterson, professor in Latyn en Hebreeus, vir Ou Testament verantwoordelik was. In 1921 is prof SP Engelbrecht as professor aangestel en in 1926 volg dr B Gemser prof Patterson op (Ad destinatum 1960: 165). In terme van die persone wat die doseerwerk gedoen het, is dit dus eers van 1921 af dat die teologiese opleiding werklik Hervormd geword het.

Van die stigting van die teologiese opleiding af was Hebreeus, Grieks, Latyn en Wysbegeerte verpligte vereistes vir elke voornemende teologiese student (Ad destinatum 1960: 165).

Wysbegeerte is met die begin van die Transvaalse Universiteitskollege in 1908 as vak ingestel en bygevoeg by die leeropdrag van prof AC Patterson, die professor in Hebreeus en Latyn. Van die middel van 1908 af tot aan die einde van die jaar was dr JH Hertz die dosent in Wysbegeerte, en aan die begin van 1909 word dr Leo Fouche die professor in Geskiedenis en Wysbegeerte, terwyl hy ook Sielkunde en Staatsleer moet gee. Gedurende 1911 doseer dr WA Macfadyen Etiek en Staatsleer en aan die begin van 1912 word hy professor in Wysbegeerte en Staathuishoudkunde. Hy doseer Logika, Metafisika, Staatsleer, Etiek en Sielkunde en gee ook nog lesings in Biologie, Stadsbeplanning, Musiek en Eugenetiek. 
Aan die begin van 1921 word dr TJ Hugo senior lektor in Sielkunde en doseer ook in Wysbegeerte. Aan die begin van 1925 volg hy prof Macfadyen as professor in Wysbegeerte op.

CH Rautenbach word in 1924 tydelike lektor en in 1925 lektor in Wysbegeerte en Sielkunde, bedank einde 1926 om Hervormde predikant te word, promoveer in 1932 in die Wysbegeerte (oor McDougall, 'n Amerikaanse sielkundige) en word in 1934 weer lektor in Wysbegeerte (Ad destinatum 1960: 93-94).

Aan die begin van 1938 word Wysbegeerte in twee departemente verdeel. Prof Hugo word hoof van die Departement Logika en Metafisika, en aan die begin van 1939 word prof Rautenbach hoof van die Departement Etiek en Geskiedenis van die wysbegeerte, benewens benoemings in Teologie, Afdeling A en in Opvoedkunde.

Die situasie bly onveranderd tot op 9 April 1948, toe prof Rautenbach rektor van die Universiteit van Pretoria word en dr CK Oberholzer in die Departement aangestel is.

Dr AMT Meyer was lektor van 1950 tot 1957 . Hy was 'n oud-student van die Departement, maar het heeltemaal weggeswaai in die rigting van die moderne logika en taalanalise. Prof Hugo het aan die einde van 1951 uitgetree en aan die begin van 1952 is dr PS Dreyer as lektor aangestel. Hy bly in die Departement tot die middel van 1986. Aan die einde van 1969 het prof Oberholzer uitgetree. Nog tydens sy dienstyd het sy dogter, dr RE Oberholzer vir twee tydperke en ook dr SJ Schoeman (later professor aan en rektor van die Universiteit van Port Elizabeth) as lektore gedien. Hulle is deur dr AJ Antonites opgevolg. Daarna is dr JHN Visage, dr JD Gericke, dr J Lamprecht (vir 'n klein rukkie), mnr GJ de Beer en mnr M Schoeman as dosente aangestel en is tans nog steeds in die Departement. Prof AP du Toit het in 1986 hoof van die Departement geword. Behalwe prof Hugo was almal oud-studente van die Departement.

Hoogstens drie of vier Hervormde predikante wat hulle studie in Pretoria gedoen het, het hulle wysgerige opleiding by prof Macfadyen ontvang. Al die ander, met die uitsondering van die enkeles wat hulle literêre opleiding aan ander universiteite gekry het, was en is wysgerig die kwekelinge van prof Hugo en sy opvolgers.

Besonderhede van prof Macfadyen se wysgerige standpunt of van sy opleiding is vir skrywer nie beskikbaar nie. Hy is egter primer in Manchester en Oxford in die Regte opgelei en het aanvanklik in Suid-Afrika as advokaat gedien. Teen die einde van die negentiende eeu, toe hy student was, was die invloed van die Vastelandse, in besonder die Duitse filosofie baie sterk aan Britse universiteite. Sonder om te beweer dat dit die geval was, sou dit nie verbasend wees as vasgestel sou word dat prof Macfadyen wysgerig hierdie invloed ondergaan het nie. Van verreweg die 
grootste belang is egter die wysgerige strominge van prof Hugo af verder, dit wil sê van 1921 af toe prof Hugo in Wysbegeerte begin doseer het, tot middel 1986 toe skrywer uitgetree het. Dit is 'n periode van vyf-en-sestig jaar.

Prof Hugo het van 1914 tot 1918 onder G Heymans aan die Rijks-Universiteit van Groningen studeer en ook gepromoveer. Hy was lewenslank 'n getroue volgeling van Heymans. So groot was Heymans se invloed op hom dat studente soms goedig spottend (want hy was 'n gerespekteerde en geliefde figuur) die geskiedenis van die Wysbegeerte in twee periodes ingedeel het, naamlik voor Heymans en Heymans; na Heymans was daar niks.

Prof Rautenbach het homself altyd 'n outodidak genoem en nie daarvan gehou dat 'n mens moet sê dat hy onder die invloed van Heymans was nie. Hy was inderdaad ook baie meer krities teenoor Heymans as wat prof Hugo was. Desondanks was hy baie sterk onder Heymans se invloed en het hy Heymans in alle wesenlike opsigte nagevolg.

Skrywer was 'n leerling van proff Hugo en Rautenbach en is in die filosofie van Heymans grootgemaak. Dit plaas ons voor die taak om baie kortliks na Heymans en die Nederlandse wysbegeerte te kyk.

Nederland het sy kwota wysgere opgelewer (vgl Faber), soos Siger van Brabant (oorlede 1282), Averroïstiese Skolastikus; Arnold Geulinx (1625-1669), gebore in Antwerpen, hoogleraar in Leuven en Leiden, Cartesiese metafisikus; Baruch de Spinoza (1632-1677), Spaans-Portugese Jood, maar gebore in Amsterdam en lewenslank in Holland woonagtig, metafisikus en een van die heel grootste Rasionaliste; en so meer. Daar was ook René Descartes, wat in Frankryk gebore is (1596) en twee jaar voor die stigting van die verversingspos aan die Kaap in Swede oorlede is, maar lank in Holland gewoon het. Hy was die voorloper van Geulinx en Spinoza, en een van die heel grootste van die moderne wysgere, wat ook as een van die voorlopers van die Modernisme groot teologiese betekenis gehad het. Dan was daar 'n paar internasionaal belangrike figure wat soms tot die wysbegeerte gereken word, maar liefs tot die geskiedenis van die teologie gereken moet word. Voorbeelde is Jan van Ruysbroeck (1293-1381) en Desiderius Erasmus van Rotterdam (14661536).

Denkers soos die bogenoemde behoort nie net tot Nederland nie, maar is van die invloedrykste figure van die geestesgeskiedenis van die Weste. Daar is geen twyfel dat Nederland graag hierdie posisie ingeneem het nie. Dit kan ons aan twee gebeure illustreer:

Die eerste is die stigting van die Universiteit van Leiden in 1575 , waarmee die trotse geskiedenis van die Nederlandse universiteitswese begin. Waar daar nie 
Nederlanders was om aan te stel nie, is vrylik van ander gebruik gemaak. So het die Skotte James Ramsay en John McCullogh en die Fransman Pierre Dumoulin almal die leerstoel in Wysbegeerte in die begintyd van die Universiteit gevul.

Die tweede is die Pasifikasie van Ghent (1566), opgevolg deur die Unie van Utrecht (1579), waarvan Artikel XII alle geloofsvervolging verbied. Dit het gemaak dat nie net Descartes en Spinoza 'n veilige toevlugsoord in Holland gevind het nie, maar ook baie ander onortodokse geeste van mindere gehalte. En dat hierdie gees van vryheid reeds lank voor die Unie van Utrecht bestaan het, word getoon deur die feit dat Thomas Morus in 1516 sy Utopia in Holland publiseer en drie jaar daar woon, omdat sy eie Engeland vir hom onveilig was en hy Holland as die veiligste oord beskou het.

$\mathrm{Na}$ Spinoza lewer Nederland nie weer 'n wysgeer van gelyke formaat nie. Die wysbegeerte word egter lewendig aan die universiteite bedryf en die gehalte daarvan hoef nie vir die deursnee filosofie van Europa agteruit te staan nie. Deurgaans bly die Nederlandse wysbegeerte 'n integrale deel van en weerkaats dit die geestesstrominge van Europa. So geniet die opbloei van die natuurwetenskappe 'n ewe begeesterde ontvangs in Nederland as elders; hoewel sonder werklike diepgang, oorspoel die Deïsme en die Aufklärung nie net die Nederlandse wysbegeerte in die agtiende eeu nie, maar in 'n groot mate ook die Nederlandse burgery en verdring die leer van die natuurlike godsdiens die Christelike godsdiens tot op 'n bedenklike hoogte; en in die negentiende eeu word Nederland net soos die res van Europa deur die filosofie van Kant, die Duitse Idealisme en later in die eeu die Neo-Kantianisme oorweldig. Dit is egter opvallend dat die Nederlandse wysbegeerte deurgaans deur die Duitse wysbegeerte gevoed is en hoofsaaklik daarop gerig was. Die Britse filosowe, byvoorbeeld Locke, Shaftesbury en Hume, is in Nederland net soos in die res van Europa gelees. In die agtiende eeu het die sogenaamde 'common sense'-filosofie selfs 'n mate van (oppervlakkige) invloed en navolging in Nederland gehad. Desondanks moet ons Nederland deurgaans (minstens sover dit die wysbegeerte betref) as deel van die Duitse denkwêreld beskou. Die Nederlandse filosowe het die Duitse wysbegeerte deur en deur geken; behalwe in Nederlands het hulle verreweg die graagste in Duits geskrywe; en die roem wat hulle buite die grense van Nederland behaal het, was in die Duitstalige wereld.

Bostaande is ook 'n skets van die agtergrond van G Heymans (1857-1930). Heymans is in Ferwerd, Friesland, gebore en het sy hoërskoolopleiding in Leeuwarden voltooi. Aan die Universiteit van Leiden studeer hy onder prof JPN Land (1834-1897), voorganger van prof GJPJ Bolland, 'n baie vooraanstaande Hegeliaan, van wie die studente in Groningen na die Tweede Werreldoorlog nog gepraat het (Bolland van Holland of Holland van Bolland, afhangende van jou gesindheid). 
Heymans promoveer in 1880, publiseer verskillende artikels en sy eerste boek Die Methode der Ethik in 1882 . In 1890 word hy benoem as hoogleraar in Wysbegeerte aan die Rijksuniversiteit van Groningen, dieselfde jaar waarin sy pryswennende Schets eener kritische geschiedenis van het causaliteitsbegrip in de nieuwere wijsbegeente verskyn. Hoewel hy aanbiedinge van verskillende universiteite ontvang het, het Heymans tot sy dood in Groningen gebly.

Toe Heymans aan Leiden afstudeer, is hy 'n oortuigde Neo-Kantiaan. Hy begin baie gou sy eie aksente in die Wysbegeerte lê, maar sy Kantiaanse grondslag het hy altyd behou. Die filosofie van Kant is in 'n baie wesenlike sin die samevoeging van die voorafgaande Rasionalisme en Empirisme in Kant se Kritisisme, maar na Kant gaan die Rasionalisme en Empirisme voort, nie meer in die ou gestaltes nie omdat Kant 'n einde daaraan gebring het, maar in rigtings soos die Idealisme en Positivisme, met baie skakerings tussenin. Heymans se koers lê baie sterk aan die empiriese kant. Deur sy veertigjarige arbeidstyd het hy telkemale herhaal dat sy werk auf Grundlage der Erfahrung gedoen word. So sterk was hy empiries ingestel dat hy die eksperiment as wetenskaplike metode nie genoeg kon beklemtoon nie. Tegelykertyd het hy herhaaldelik bygevoeg dat hy empiries te werk gaan om tot bowe-empiristiese gevolgtrekkings te kom:

Wenn einer mich auffordern sollte, möglichst kurz zu sagen, wodurch eigentlich meine philosophischen Untersuchungen sich von denjenigen der meisten Zeitgenossen unterscheiden, so würde ich antworten: 'dadurch, dasz diese Untersuchungen überall empirische Methoden verwenden und dennoch ebenso allgemein zu anti-empiristischen Ergebnissen gelangen' (Heymans 1927: 1).

Die invloed van Kant blyk die duidelikste uit sy fundamentele oortuiging dat ons nie die werklikheid ken soos dit in sigself bestaan nie, maar soos dit aan die kennende gees verskyn, en dat kennis altyd die resultaat van die bewussyn se verwerking van die empiriese gegewens is. Juis dit het Heymans groot bekendheid in Duitsland gegee.

Heymans wyk egter van Kant daarin af dat hy aan sy filosofie 'n baie sterk psigologiese wending gee. Omdat kennis die resultaat van die bewussyn se verwerking van sintuiglike gegewens is, is alle kennis volgens Heymans aan psigiese prosesse verbind, en moet die wysbegeerte, in besonder die etiek, kennisleer (ook die logika) en metafisika ook vanuit psigologiese hoek bekyk en verstaan word. As gevolg hiervan het Heymans net soveel werk op die terrein van die sielkunde as op die gebied van die wysbegeerte gelewer. Die psigologie wat hy beoefen het, was 'n 
eksperimentele psigologie, maar geskoei op die lees van Wilhelm Wundt. In 1892 het Heymans reeds met so 'n psigologiese instituut begin, wat sedert 1927 as die Psychologisch Instituut-Heymans bekend staan.

Sy empiriese ingesteldheid het hom ook intens in die natuurwetenskap laat belang stel. Veral die ontluikende Mikrofisika het hom baie sterk beïnvloed, egter sonder dat dit hom aan die absolute en universele geldigheid van die wet van oorsaak en gevolg laat twyfel het. Die mikrofisika gee hom die geleentheid om sy psigies-monisme as metafisiese sisteem te ontwikkel, maar sy vasklou aan die wet van oorsaaklikheid laat hom in onoorkomelike probleme ten opsigte van die Etiek beland (Dreyer 1946; 1957).

Toe die jong TJ Hugo van 1914 tot 1918 aan die Universiteit van Groningen studeer het, was Heymans op die hoogtepunt van sy bekendheid. Sy Die Gesetze und Elemente des wissenschaftlichen Denkens het vir die eerste keer in 1894 verskyn, die vierde druk in 1923. Einfuihrung in die Metaphysik auf Grundlage der Erfahrung verskyn in 1905, derde druk 1934. Die laaste van sy groot wysgerige werke, Einführung in die Ethik auf Grundlage der Erfahrung, verskyn vir die eerste keer in 1914, die derde druk in 1934. Gedurende hierdie jare verskyn talle artikels en kleiner werke op die psigologiese so goed as die wysgerige gebied. Die belangrikste hiervan is in 1927 gebundel in drie lywige bande onder die titel Gesammelte kleinere Schriften zur Philosophie und Psychologie. Erster Teil: Erkenntnistheorie und Metaphysik. Zweiter Teil: Allgemeine Psychologie, Ethik und Aesthetik. Dritter Teil: Spezielle Psychologie.

Opvallend is ook wat by Heymans ontbreek. Die grootste wysgere van die twintigste eeu (tot so ver as wat ons nou is) was sy tydgenote: Edmund Husserl (1859-1938), Martin Heidegger (1889-1985), Karl Jaspers (1883-1969), Helmuth Plessner (1892-1983) en die res van die groot manne van die eksistensiefilosofie en die wysgerige antropologie. Van al hierdie figure verwys hy net baie kort in sy Gesetze und Elemente des wissenschaftlichen Denkens na Husserl, waar hy laasgenoemde se kritiek op die psigologisme in die Kennisleer verwerp. Karl Marx is oorlede tien jaar nadat Heymans die leerstoel in Groningen aanvaar het, maar ook Marx en die ander Jong-Hegeliane kry geen aandag in Heymans se werk nie. Dit is asof hy hierdie strominge eenvoudig as non-filosofie ignoreer.

In 1927 is Heymans deur Leonard Polak (1880-1941) opgevolg. Polak en enkele ander, soos JJ Poortman en HJFW Brugmans, was getroue voortsetters van Heymans se filosofie. Sover aan skrywer bekend het geen Suid-Afrikaanse wysgeer onder hulle studeer nie.

As ons nou ons aandag by proff Hugo, Rautenbach en Oberholzer (voor ongeveer 1950) bepaal, merk ons die invloed van Heymans baie gou op. Die ruimte 
ontbreek om op besonderhede in te gaan en ons bring net die volgende na vore:

- In hulle doseerwerk het aldrie swaar op Heymans se werke geleun en uitgebreid daarvan gebruik gemaak, ook as voorgeskrewe materiaal vir studente. Die Wysbegeerte-studente van daardie jare het Heymans baie goed geken en sy filosofie het as die basiese materiaal gedien waarvolgens hulle denke gevorm is.

Aldrie het, net soos Heymans, naas die wysbegeerte ook in die psigologie belang gestel en was met tye dosente in die Sielkunde, 'n belangstelling wat Heymans minstens sterk aangewakker het. Aldrie het, soos Heymans, kennis onlosmaaklik aan psigiese prosesse verbind en groot nadruk daarop gelê. Die psigologisme in die wysbegeerte, in die sin wat so sterk deur Husserl, Alexander Pfänder en andere bestry is, was kenmerkend van Heymans en eweseer van sy leerlinge.

- Die aanhaling hierbo uit Heymans se Selbstdarstellung het skrywer male sonder tal voorgraads en nagraads, in die klas en daarbuite, van aldrie professore gehoor as die formulering van die basiese metode van die Wysbegeerte. Prof Rautenbach het dit beskou as die fundamentele kenmerk van alle wetenskaplike werk. Op sy eie kenmerkende wyse het hy graag gesê wetenskap het altyd met feite te doen, en feite is koppige goed wat 'n mens dwing om met hulle rekening te hou. Feite op sigself is egter nog niks. Die feite moet met steekhoudende logika verwerk word, waardeur 'n mens tot besluite kan kom wat algemene geldigheid besit en daarom bo die blote feitelikheid uitstyg.

- Beide prof Hugo en prof Rautenbach het min eg wetenskaplike werk gepubliseer. Prof Oberholzer se ryp wetenskaplike werk is eers na ongeveer 1950 uitgegee, maar in sy proefskrifte en verhandeling is die invloed van Heymans baie duidelik. Die beste voorbeeld van gepubliseerde werk uit hierdie tydperk is prof Rautenbach se Sedelike keuring (kritiek op McDougall), wat in sy oorspronklike vorm as proefskrif gedien het, maar in verwerkte vorm in 1939 verskyn het. Die eerste afdeling van hierdie werk is in prof Rautenbach se Versamelde geskrifte opgeneem (Dreyer 1975: 37vv). In hierdie werk val dit in die eerste plek dadelik op dat prof Rautenbach oor 'n figuur werk wat baie met Heymans gemeen het, naamlik McDougall, 'n Amerikaanse psigoloog wat hom onder andere baie met die Etiek besig gehou het. Tweedens sien 
ons reeds op die eerste bladsy (bl 37; die bladsynommer kom uit die afdruk van Sedelike keuring in die Versamelde geskrifte) dat prof Rautenbach by Heymans aansluit om die strekking van wetenskaplike kritiek te formuleer. Van bladsy 39 af werk prof Rautenbach die struktuur van die ervaringswetenskap uit, wat moet dien as die fundamentele uiteensetting van hoe hy die Etiek sien. Dit loop dwarsdeur die werk en kort-kort verwys hy na Heymans, by wie hy ondersteunende gedagtes kry.

Heymans se invloed in die Departement Wysbegeerte aan die Universiteit van Pretoria was oorweldigend oor 'n periode van dertig jaar. Na die Tweede Wêreldoorlog het dit egter ten einde geloop.

Die vroegste geformuleerde uiting van hierdie ontwikkeling waarvan ek weet, is my verhandeling Oorsaaklikheid en vryheid: 'n Kritiese vergelyking tussen Kant en Heymans, wat onder prof Rautenbach se leiding geskryf is. Tot aan die begin van hierdie studie was ek ' $n$ verbete volgeling van Heymans. Die effekte van die studie was dat ek 'n Kantiaan geword het - 'n egte Kantiaan in die sin van Kant se eie werke en nie in die betekenis van die Neo-Kantianisme nie, maar wel 'n Kantianisme getemper en begrens vanuit die teologie. Hoewel hierdie studie my baie sterk krities teenoor Heymans laat staan het, was ek in 'n baie groot mate nog steeds van Heymans afhanklik, omdat hy die enigste twintigste-eeuse wysgeer is wat ek werklik geken het.

In die Sedelike keuring blyk dit baie duidelik dat prof Rautenbach hom ook met Husserl en die fenomenologie besig gehou het. Hy staan nie heeltemaal negatief daarteenoor nie, maar kies sonder twyfel die gesigspunt van Heymans. Dit blyk ook baie duidelik uit ons verdere verhouding. Nadat ek die MA in 1946 voltooi het, wou ek aan die doktorale eksamen begin werk en het met prof Rautenbach daaroor gaan praat. Met ons eerste gesprek het hy min of meer die volgende woorde gebruik: 'Daar is 'n nuwe ding in Europa aan die gang. Hulle noem dit wysgerige antropologie. Ek weet nog nie behoorlik wat dit alles insluit nie, maar ek dink jy moet daaraan begin werk'. Die lys van dertig werke wat hy voorgeskryf het, het sommige baie tersaaklike werke ingesluit, maar ook 'n aantal wat vaagweg kultuurfilosofie genoem kan word. Waarvan ek later baie bewus geword het, is dat daar geen werke van die fenomenologiese rigting, van Husserl se skool of van Jacob von Uexküll se skool, in die lys voorgekom het nie. Toe ek aan die einde van 1947 vir verdere studie Europa toe wou gaan, het ek prof Rautenbach geraadpleeg. Sy antwoord was: 'Die oorlog het ons so lank van Europa afgesluit dat ons nog nie behoorlik weet wat daar aangaan nie, maar ek dink jy moet Groningen toe gaan.

Leo Polak is dood en ek weet nie wie hom opgevolg het nie, maar daar sal wel nog 
iets van Heymans oor wees'.

Aan die begin van Januarie 1948 het ek in Groningen aangekom. Al wat van Heymans oor was, was sy borsbeeld aan die voet van die trap in die Akademiegebou. Later het ek uitgevind dat HJFW Brugmans nog die leerstoel in Sielkunde beklee het. Hy was 'n oortuigde volgeling van Heymans, maar het weinig studente getrek. Die opvolger van prof Leo Polak as hoogleraar in Wysbegeerte was prof Helmuth Plessner, leerling van Edm Husserl en Jacob von Uexküll, tot op die huidige nog steeds die grootste figuur van die wysgerige antropologie. Dit het vereis dat ek die wysbegeerte na Kant behoorlik onder die knie moes kry, vir die eerste keer. Dit het impliseer die wysbegeerte van Hegel en die Jong-Hegeliane waarvan Karl Marx en Sören Kierkegaard die belangrikste is (my proefskrif het oor die antropologie van Ludwig Feuerbach gegaan); verder Edm Husserl en die fenomenologiese beweging; en laastens die wysgerige antropologie en die eksistensiefilosofie, wat sedert die Eerste Wêreldoorlog op die voorgrond gekom het. 'n Tyd in Basel by Karl Jaspers en Karl Barth het baie gehelp. Toe ek in Augustus 1950 in Suid-Afrika aankom, was ek 'n groter bewonderaar van Kant as ooit en 'n kritiese aanhanger van die fenomenologiese metode. Ek het my by die stroom van die wysgerige antropologie geskaar en was 'n versigtige student van Martin Heidegger.

Kort na my vertrek na Nederland, in April 1950, is prof Rautenbach as rektor aangewys en prof CK Oberholzer as professor in Wysbegeerte aangestel.

Teen 1950 het prof Oberholzer reeds heeltemaal van Heymans af weggebreek. In hierdie opsig was hy heeltemaal 'n outodidak. Langs die weg van tydskrifte en boeke wat hy self uit die buiteland bestel het, het hy homself behoorlik op die hoogte van die byderwetse wysgerige strominge gebring. Hy het nie net die wysgerige antropologie heeltemaal bemagtig nie, maar mettertyd sy eie rigtings, naamlik die mediese antropologie en die toepassing van die wysgerige antropologie op die Opvoedkunde, ontwikkel. Veral op laasgenoemde terrein het hy ook buitelandse erkenning gekry. Hy was 'n buitengewoon goeie kenner van Husserl en die fenomenologie. Op die gebied van die eksistensiefilosofie was hy aanvanklik 'n groot bewonderaar van Karl Jaspers. Later het sy bewondering na Martin Heidegger omgeswaai.

Prof Oberholzer se invloed het baie verder as die Universiteite van Pretoria en Suid-Afrika gestrek, maar vir die doeleindes van hierdie artikel is dit belangriker om daarvan kennis te neem dat hy 'n volledige hervorming van die Wysbegeerte aan die Universiteit van Pretoria deurgevoer het. Die nuwe strominge wat hulle plek in die doseerwerk gevind het, was egter nog steeds deur en deur Vastelands-Europees georiënteer. Die klem het egter heeltemaal van Nederland af na Duitsland, Switserland en in 'n mate Oostenryk verskuiwe. Die geweldige rol wat die Wysbegeerte in 
Europa na die Eerste Wêreldoorlog begin speel het, die opkoms van die sosialisme en kommunisme en die kultuurkrisis waarin die Weste gedompel is, het meegebring dat die geestesgeskiedenis van Europa buitengewoon baie aandag in die Departement ontvang het.

Prof Hugo het aan die einde van 1951 uitgetree en aan die begin van 1952 is ek as lektor aangestel. Met prof Oberholzer se uittrede aan die einde van 1969 het ek hoof van die Departement geword. Middel 1986 het ek uitgetree. Die rigting wat prof Oberholzer begin het, is deur die jare voortgesit, hoewel daar baie klemverskuiwings was en nuwe kursusse (bv oor Marx en die Neo-Marxisme) ingevoer is.

Uit hierdie kort opsomming van die geskiedenis van die Departement Wysbegeerte aan die Universiteit van Pretoria is minstens een ding duidelik: Ondanks veranderinge in wysgerige rigting en in die belangstellingsveld van individuele wysgere was die denke van die Departement vir die byna sewentig jaar na 1917 onlosmaaklik 'n deel van die denkwêreld van Nederland en die Duitstalige wèreld. Dit was ook in 'n groot mate ons poort van toegang tot die res van die wèreld. Die Wysbegeerte het teen dieselfde agtergrond beweeg en in dieselfde soort klimaat gedy as die Teologie, veral dié teologie wat in die Fakulteit Teologie, Afdeling $A$ beoefen is. Die inhoud van wat die teologiese studente in die Wysbegeerte geleer het, maar baie meer nog die geestelike vorming en denkdissipline wat hulle ontvang het, kon nie anders as om van betekenis vir die teologiese opleiding te gewees het nie. Wysbegeerte was vir die teologiese studente nie maar net nog 'n vak in die voorstudie nie. Sonder dat daar ooit teologie in die Departement Wysbegeerte doseer is, of pogings aangewend is om tot 'n Christelike wysbegeerte te kom, en tussen 1952 en 1986 nooit samesprekings oor kursusse of rigtings tussen Teologie en Wysbegeerte plaasgevind het nie, was daar 'n gemeenskaplike agtergrond, 'n geestesklimaat, afgestemdheid en gerigtheid wat nie net tot voordeel van die teologiese opleiding gestrek het nie, maar ook noodsaaklik daarvoor was.

\section{Literatuurvewrwysings}

AD DESTINATUM: GEDENKBOEK VAN DIE UNIVERSITEIT VAN PRETORLA.

1960. Johannesburg: Voortrekkerpers.

DREYER, PS 1946. Oorsaaklikheid en vryheid: 'n Kritiese vergelyking tussen Kant en Heymans. MA-verhandeling, Universiteit van Pretoria.

DREYER, PS 1957. Oorsaaklikheid en vryheid. HTS 13/1.

DREYER, PS (red) 1975. Prof CH Rautenbach: Versamelde geskrifte. Pretoria: HAUM.

FABER, W s a . Wijsgeren in Nederland. Nijkerk: Callenbach. 
GEDENKALBUM 1886 - 1986 VAN DIE NEDERDUITSCH HERVORMDE KERK VAN AFRIKA IN WOORD EN BEELD. Pretoria: NHW-pers.

HEYMANS, G 1927. Selbstdarstellung, in Gesammelte kleinere Schriften zur Philosophie und Psychologie, Erster Teil: Erkenntnistheorie und Metaphysik. Haag: Martinus Nijhoff. 